\title{
CHARACTERISTICS AND POSSIBLE FUNCTIONS OF TRADITIONAL NIGHT ROOSTING AGGREGATIONS IN RUBYSPOT DAMSELFLIES
}

\author{
by
}

\author{
PAUL V. SWITZER ${ }^{1,2)}$ and GREGORY F. GRETHER ${ }^{3,4)}$ \\ ( ${ }^{1}$ Department of Biological Sciences, Eastern Illinois University, Charleston, IL 61920, \\ USA; ${ }^{3}$ Department of Organismic Biology, Ecology, and Evolution, University of \\ California, Los Angeles, CA 90095, USA)
}

(Acc. 12-XII-1999)

\begin{abstract}
Summary
Many species of animals congregate into groups when roosting. While studies exploring roosting behavior are common, relatively few detailed, quantitative studies have been done on the roosting behavior of insects, and the adaptive value of roosting aggregations are still unclear for most edible (non-distasteful) species of any taxon. We investigated night roosting aggregations of the rubyspot damselfly, Hetaerina americana, along a creek in the Coastal Range Mountains of California. Both male and female rubyspots were found in roosting aggregations, although the aggregations tended to be male-biased relative to the population sex ratio. Rubyspots roosted on the west side of slow moving sections of the creek; within this habitat they were highly aggregated but were not associated with any particular habitat features. The spatial pattern of site use tended to change gradually over time and sites with a relatively large number of individuals were more likely to be used on subsequent nights. These results suggest that within suitable habitat, the specific locations of roosting aggregations were traditional (socially learned). Rubyspot roosting patterns, when taken in combination with other aspects of this species' biology, do not support habitat limitation, thermal or desiccation benefit, foraging, and aposematic hypotheses for the function of rubyspot roosting aggregations. Rather, the roosting aggregations most likely serve an antipredator function or are the result of using conspecifics to choose safe sites.
\end{abstract}

2) Corresponding author; e-mail address: cfpvs@eiu.edu

4) We would like to thank Jeff Grether and Edy Hayashi for field assistance during this project, Richard Grey for identifying plants, and Anthony Smernes Jr. for permission to use the land. B. Grether and I. and J. Switzer provided helpful comments on the manuscript. 


\section{Introduction}

Many insects aggregate while foraging, mating, or roosting (reviewed in Wynne-Edwards, 1962; DeVries et al., 1987; Miller, 1989; Vulinec, 1990). Roosting aggregations are particularly interesting, for although the behavior exists in orders as widespread as Coleoptera, Hemiptera, Hymenoptera, Lepidoptera, and Odonata (Rau \& Rau, 1916; Corbet, 1962; Copp, 1983, Brönmark et al., 1984; DeVries et al., 1987), and may occur during the day or night (e.g. Mallet, 1986; DeVries et al., 1987), the general behavior pattern is much the same. Individuals aggregate into relatively tight, motionles s groups, and while the membership of groups may vary, the sites of aggregation are often stable over time (e.g. Benson \& Emmel, 1973; Greig \& DeVries, 1986; DeVries et al., 1987; Miller, 1989; Neubauer \& Rehfeldt, 1995).

Although roosting aggregations are widespread among insects, they remain poorly studied in this group. Of the few detailed studies, most are of aposematic taxa with chemical defenses against predation, such as $\mathrm{He}$ liconius butterflies and ladybird beetles (reviewed in Vulinec, 1990; but see Treherne \& Foster, 1980). Even among these better studied species, most investigation s focus on a small number of roosts, so the generality of the observed roosting patterns is not known. Consequently, we still have a great deal to learn about most aspects of insect roosting behavior, particularly for non-aposematic, edible species. For example, many odonate (damselfly and dragonfly) species aggregate at night (reviewed in Corbet, 1962; Neubauer \& Rehfeldt, 1995) but our knowledge of odonate roosting aggregations is still largely qualitative and anecdotal.

In this paper, we present results from a detailed observational study of nocturnal roosting behavior of the rubyspot damselfly, Hetaerina americana. During the warm hours of the day, competitive rubyspot males defend small territories along stream riffles (Grether, 1996a), while females (unless mating and laying eggs) and young males tend to remain relatively inconspicuous in streamside vegetation. Before and after the territorial period, all rubyspots hunt for small, flying insects along slow sections of the stream (Grether \& Grey, 1996). In the evening, rubyspots fly to their roosting sites and settle onto the vegetation either solitarily or in groups.

Rubyspots have a number of characteristics that make them ideal for investigating night roosting aggregations. They can be easily caught, marked, 
aged, and sexed and range over a relatively small distance (Grether, 1996a, b). Furthermore, they occupy single-species roosts, a large number of which can occur simultaneously in the same area (see results). Consequently, roosting behavior is not confounded by heterospecific roostmates and a large number of individuals can be followed among roosts over the course of their lifetimes.

Elsewhere, we present information on rubyspot roost site fidelity in relation to sex and territorial status (Grether \& Switzer, in press). We found that both male and female rubyspots were faithful to their previous night's roost site. However, if a male obtained a territory relatively distant from his current roost site, he tended to shift his roost site closer to his new territory over the course of a few days. Additionally, males did not roost in locations that decreased the total daily commuting distance among their roost, territory, and hunting sites; this result allowed us to reject the primary prediction of one functional explanation for roosting aggregations, the patchsitting hypothesis (Caccamise \& Morrison, 1986).

Here we focus on the location and distribution of rubyspot roost sites. Specifically, we answer the following questions about the roosting behavior of rubyspots: (1) How are roost sites distributed relative to characteristics of the environment? (2) How does the distribution of roost sites change over time? (3) How are animals distributed among the utilized sites? (4) Are there sex differences in roosting behavior? We use the answers to these question s to address the function of the habitats selected for roost sites, to determine the degree to which roost locations can be viewed as traditional, and to test additional functional hypotheses for roosting aggregations in this species.

\section{Methods}

This study was conducted along a $134 \mathrm{~m}$ section of Bear Creek, a spring-fed stream in Colusa County, California $\left(39^{\circ} 01^{\prime} \mathrm{N}, 122^{\circ} 23^{\prime} \mathrm{W}\right.$, elevation $260 \mathrm{~m}$ ). All rubyspots in this creek section were marked shortly after emergence or immigration on their left hindwing with a unique number using a black Sharpie pen.

Data describing the characteristics of roosting individuals and roosting sites were collected during population censuses on 58 consecutive days (25 August-21 October 1991) between 0500 and $0900 \mathrm{hrs}$. Additional daily censuses were conducted at hours that rubyspots were active, to obtain accurate estimates of population density and demography. During censuses, the identification number, sex, and location of each rubyspot was recorded. Location data included the bank (east or west), distance along the creek with respect to marker flags (to $0.5 \mathrm{~m}$ ), and distance from the creek (to $0.5 \mathrm{~m}$ ). We measured current speed by recording the 
time it took a plastic bobber to travel $1 \mathrm{~m}$ after reaching the speed of the current; depending on the speed in the nearest part of the creek, roost sites were classified as 'slow' $(<0.5 \mathrm{~m} / \mathrm{s})$ or 'fast' $(\geqslant 0.5 \mathrm{~m} / \mathrm{s})$.

The roosts of this species do not have discrete physical boundaries (see Results). To compare the spatial distribution of roosts across nights, we assigned a unique number to each $0.5 \times 0.5 \mathrm{~m}$ cell in a $134 \times 32.5 \mathrm{~m}$ grid centered on the creek $(17420$ cells, 15464 on land) This enabled us to determine the degree of overlap of site use on different nights without drawing arbitrary boundaries between sites. It was necessary to draw boundaries, however, to determine the number of animals at a particular roost. We assumed that individuals separated by more than $0.5 \mathrm{~m}$ of unoccupied space were members of different roosts, and therefore define a 'roost' as the individuals occupying a set of contiguous occupied $0.25 \mathrm{~m}^{2}$ cells. We use 'roosting aggregations' to refer to roosts of more than one individual and 'roosting site' to refer to the location where the individual( $\mathrm{s}$ ) roosted.

Roost aggregation size was ln-transformed to meet the assumptions of the statistical tests. Non-parametric statistics were corrected for ties. Untransformed means and their standard errors are presented in the text. The $p$-values we report are two-tailed.

\section{Results}

\section{Roost site preferences}

Roosting rubyspots were concentrated along the west bank of slow sections of the creek. Of 6817 recorded roosting sites (one per animal per night), all were within $12 \mathrm{~m}$ of the creek, $5520(81 \%)$ were within $0.5 \mathrm{~m}$ of the creek, and $6618(97 \%)$ were on the west bank (though the east bank contained similar vegetation). Among roosting sites found within $0.5 \mathrm{~m}$ of the creek, $3766(68 \%)$ were found along the $64 \mathrm{~m}(48 \%)$ of creek that was classified as having slow current. The number of sites along slow sections exceeded that expected by chance on 54 out of 58 days (Sign test, $p<0.0001$ ).

Roosting animals perched exclusively on vegetation and primarily in the upper portions of living plants, usually 0.2-2 $\mathrm{m}$ above the ground or water. On the west bank of slow sections of the creek, roosting sites did not appear to be associated with specific microhabitat features that might be related to vegetation type or distance from water. Sites occurred on most vegetation types found along the banks of the stream (including Centaurea solstitialis, Cichorium intybus, Heliotropium curassavicum, Scirpus spp., Tamarix parviflora, Toxicodendron diversilobum, and Xanthium strumarium) and occurred both in the relatively short vegetation along the vertical bank directly above the water and in the taller emergent or edge vegetation. Furthermore, on a given night, the number of vacant sites appeared to greatly 


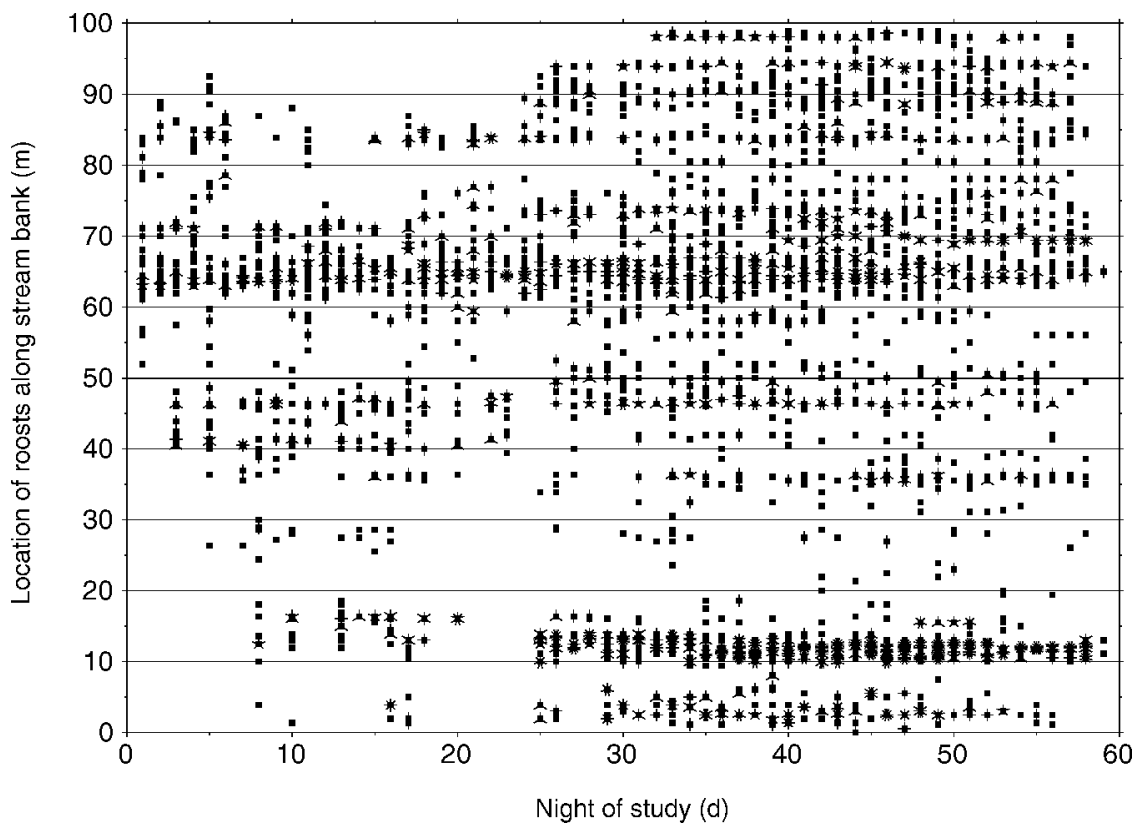

Fig. 1. Location of roosts (to $0.5 \mathrm{~m}$ ) along a $100 \mathrm{~m}$ stretch of Bear Creek on 58 consecutive nights (25 August to 21 October 1991). Only roosts along the west bank of the creek are shown $(N=4875)$. Roosts east of the creek $(N=182)$ or greater than $0.5 \mathrm{~m}$ west $(=1145)$ were excluded to simplify presentation. The number of rubyspot damselflies at the same location on the same day is indicated by short lines projecting from the corresponding points; unadorned points correspond to solitary animals.

exceed the number occupied. If unidentified environmental factors further restricted the distribution of roosting sites, these factors must have changed temporally: of the 200 cells bordering the creek on the west bank, 183 (92\%) were occupied at least once during the study (Fig. 1).

\section{Roost prevalence and size}

The number of roosting sites in the study area ranged from 7 to 71 per night, for a mean of $37.18 \pm 2.40$. Roosting sites ranged in area from 0.25 to $2.75 \mathrm{~m}^{2}$ of vegetation ( $1-11$ cells) for a mean of $0.334 \pm 0.004 \mathrm{~m}^{2}(1.34 \pm 0.02$ cells, $N=2119$ roosts $)$. Roughly half of the roosts $(N=1095)$ contained a solitary individual, while the remainder contained aggregations of 2 to 65 individuals (mean, $5.58 \pm 0.21$ ). The density of animals within groups ranged from 8 to 120 per $\mathrm{m}^{2}$ of vegetation (mean, $13.66 \pm 0.37$ ). 


\section{Spatial and temporal patterns in roost site use}

Four patterns in roost site use can be inferred from Fig. 1: (1) on a given night, the animals showed a clumped distribution among the occupied sites, (2) across nights, some sites were used more consistently than others, (3) sites with larger aggregations were more likely to be used on subsequent nights, (4) the pattern of site use changed gradually over time. Below we test these inferences statistically.

To test inference 1 (clumping among occupied sites), we compared the observed distribution of animals among occupied cells to a Poisson (random settlement) distribution separately for each night of the study. This conservatively tests for clumping among individual cells that were occupied on a given night, as opposed to the set of cells which could potentially be occupied. In a Poisson distribution, the ratio of the variance to the mean (the coefficient of dispersion, or $\mathrm{CD}$ ) equals one. An observed $\mathrm{CD}>1$ indicates clumping, while an observed $\mathrm{CD}<1$ indicates dispersion. Across the 58 nights of this study, the CD ranged from 1.00 to 11.42 , with a mean \pm se of $5.30 \pm 0.36$ which is significantly greater than one $(t=12.004$ $\mathrm{df}=57, p<0.0001)$. The distribution of animals among occupied cells was significantly clumped on 50 of 58 nights (chi-square goodness-of-fit tests with test-wise $\alpha=0.05$ ). Hence, rubyspots were clumped within roosting sites, even when the analysis was limited to occupied sites.

To test inference 2 (consistency of site use), we compared the observed rates of occupancy to that expected from a uniform (random settlement) distribution for cells occupied on one or more nights. Potentially unsuitable cells that never were occupied were excluded from this and all subsequent analyses. The observed frequency of cell occupancy ranged from 1 to 49 nights, for a mean of $3.90 \pm 0.23$ nights $(N=726$ cells $)$. The observed distribution deviated significantly from uniform (Chi-square goodness of fit test, $\chi^{2}=1035.85$, df $=71, p<0.0001$; cells were grouped into sets of 10 for this analysis), confirming that some roost sites were used more consistently than others.

To test inference 3 (aggregation size and consistency of roost site use) we classified each cell according to whether it was occupied on the night following its first recorded use. Cells that were occupied on the second night had significantly more occupants on the first night (mean, $2.06 \pm 0.14$, $N=65)$ than those that were empty on the second night $(1.44 \pm 0.04$, 


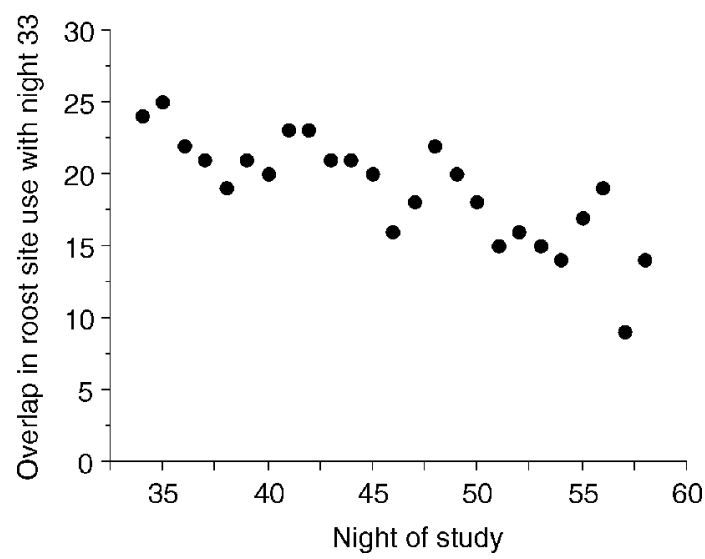

Fig. 2. Example of the decrease in overlap (number of cells in common) between the night roost census on 26 Sept 1991 (night 33) and censuses on the following 25 nights. Each point represents the number of $0.25 \mathrm{~m}^{2}$ cells that contained one or more rubyspot damselflies on 26 Sept and the day indicated on the horizontal axis.

$N=661$; Mann-Whitney test, $z=7.09, p<0.0001)$. Overall, cells with a greater mean number of occupants (on nights they were occupied) were occupied on more nights (Spearman rank correlation, $r_{\mathrm{S}}=0.62, z=16.78$, $N=726, p<0.0001)$. Therefore, sites with larger roosting aggregation $\mathrm{s}$ were more likely to be used again.

To test inference 4 (pattern of roost site use changing over time), we calculated the percentage overlap in cell use (i.e., the number of cells occupied in common) for all pairwise combinations of nights, and used Spearman correlations (between percent overlap and the number of days elapsed between nights) to measure the change in overlap over time from each of 56 possible starting dates. Figure 2 shows an example of the change in overlap over time using a single starting date. If the pattern of roost site use remained constant during the study, the expected value for the Spearman correlations would be zero. However, 54 of the 56 Spearman correlations (one per starting date) were negative, and of the 53 correlations with $N>4$ (required for 2-tailed $p<0.05$ ), 37 were significant (at test-wise $\alpha=0.05$ ). The median Spearman correlation was significantly less than zero (median $r_{\mathrm{S}}=-0.55$; Wilcoxon test $\left.z=-6.44, N=56, p<0.0001\right)$. Thus, although some roost sites clearly were more popular for roosting than others (inference 2), which sites were popular changed during the study. 


\section{Aggregation occupancy and sex ratio}

Eighty-five $(8.3 \%)$ of the roost aggregations contained only females, 290 $(28.3 \%)$ contained only males, and the remaining $649(63.4 \%)$ contained individuals of both sexes. Across nights, the mean sex ratio of aggregation s was male-biased (with sex ratio calculated as $N_{\mathrm{m}} /\left(N_{\mathrm{m}}+N_{\mathrm{f}}\right)$ : range, 0.460.86 ; mean, $0.65 \pm 0.01 ; N=58$ nights). The sex ratio of the population was also male-biased during the same time period (range, 0.55-0.80; mean, $0.62 \pm 0.01 ; N=58$ ) because females have higher mortality than males (Grether, unpubl. data), but the sex ratio of aggregations exceeded the sex ratio of the population on 44 of 58 nights (Sign test, $p<0.0001$ ). Hence, aggregations were more male-biased than expected from the population sex ratio.

The finding that roosting aggregations were male-biased relative to the population sex ratio suggests that males were more likely to join aggregations (or more likely to be joined) than females. To test this inference more directly, we calculated the mean roost aggregation size experienced by each individual during the course of the study. On average, males were found in significantly larger aggregations than females (mean roost group size of males, $11.53 \pm 0.47, N=456$; of females, $8.34 \pm 0.47, N=368$; unpaired $t$ test, $t=6.68, p<0.0001)$.

The results above leave little doubt that males were clumped among occupied sites, but were females? To answer this question, we compared the observed distribution of animals among cells to Poisson expectation s (see above) for each sex separately. This approach tests for clumping of females with females, and of males with males. The $\mathrm{CD}$ of females ranged from 0.00 to 3.63 while the $\mathrm{CD}$ of males ranged from 0.95 to 11.75 . The mean $\mathrm{CD}$ of both sexes was significantly greater than one (female mean, $1.83 \pm 0.11$, $t=7.60, \mathrm{df}=57, p<0.0001$; male mean, 4.59 $\pm 0.34, t=10.51, \mathrm{df}=57$, $p<0.0001)$, though the mean CD of males significantly exceeded that of females $(t=8.28, \mathrm{df}=57, p<0.0001)$. In short, both sexes were clumped among occupied roost sites, but males were more clumped than females.

\section{Air temperature and population density effects}

The clumping of animals among sites increased during the study, while nighttime air temperatures decreased and population density increased (Fig. 3). Was the increase in clumping a response by the animals to the 

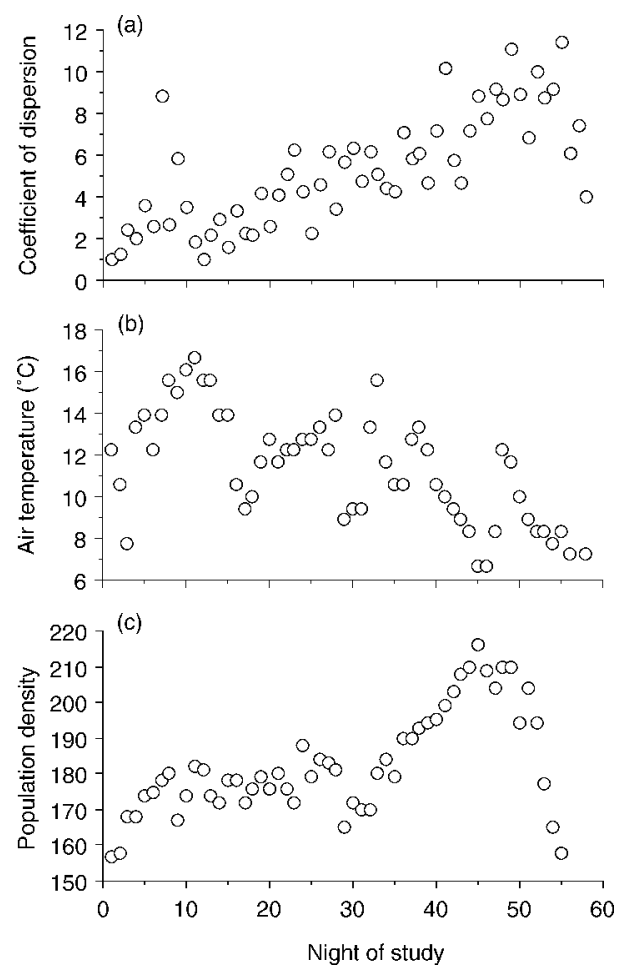

Fig. 3. Seasonal changes in (a) aggregation of damselflies among roosts, represented by the coefficient of dispersion (CD), (a) night time air temperature $\left({ }^{\circ} \mathrm{C}\right)$, measured before sunrise at 0700 hours, and (c) population density, number of adult rubyspots in the $134 \mathrm{~m}$ study creek section.

change in temperature? In a multiple regression of $\mathrm{CD}$ versus date, temperature, and population density, only date had a significant partial regression coefficient (restricted to nights 1-49, when the change in population density was approximately linear: adj. $R^{2}=0.54, N=49$; date, $\mathrm{b}=0.56$, $p<0.005$; temperature, $\mathrm{b}=-0.04, p>0.7$; density, $\mathrm{b}=0.20, p>0.2$ ). With date excluded from the model, the adjusted $R^{2}$ was lower $(0.45)$ and only population density had a significant partial regression coefficient (temperature, $\mathrm{b}=-0.16, p>0.15$; density, $\mathrm{b}=0.62, p<0.0001)$. Inspection of Fig. 3 shows that variation in $\mathrm{CD}$ did not track variation in temperature closely. Thus, we have no evidence that temperature influenced the tendency of rubyspots to aggregate at night. Increasing population density, or some other correlate of date, probably caused the increase in clumping observed during this study. 


\section{Discussion}

During this study, rubyspot damselflies (Hetaerina americana) roosted primarily on the upper portions of plants on the west bank of slow moving sections of creek. Otherwise, roosts did not appear to be associated with specific habitat features. Some sites were more popular for roosting than others, but the location of popular roosts shifted over time. The animals showed a clumped distribution among the occupied sites, forming groups of up to 65 individuals; these groups were male-biased relative to the population sex ratio. Aggregation increased during the study, perhaps because the population density increased.

Although roosting aggregation s occur in other odonates (reviewed in Corbet, 1962; Neubauer \& Rehfeldt, 1995), few studies have examined odonate roosting aggregations in detail. Like rubyspots, the dragonfly Potamarcha congener aggregates into roosts among suitable sites, and these roost locations are relatively stable from night to night (Miller, 1989). The sex ratio of $P$. congener aggregations, however, was approximately 1:1 (the sex ratio was not compared to the population sex ratio; Miller, 1989). Neubauer \& Rehfeldt (1995) found that the sex ratio of roosting aggregations of the damselfly Calopteryx haemorrhoidalis were similar to the population sex ratio and, in further contrast with rubyspot roosts, roosts of $C$. haemorrhoidali s appeared to be associated with particular vegetation (i.e. bramble leaves). These observations led the authors to conclude that the aggregations were a result of limited habitat, rather than to some benefit of aggregating (Neubauer $\&$ Rehfeldt, 1995). Thus, even with a limited number of studies it is apparent that aggregation structure varies within odonates. Below, we discuss the particular nature of rubyspot roosting behavior in light of two functional categories: the function of the habitat selected for roosting and the function of the aggregations.

\section{Choice of roosting habitat and the traditional nature of roosts}

The preference of rubyspots for roosting along the west bank of slow sections of the creek can perhaps be understood in view of the thermoregulatory and hunting behavior of this species. Because Bear Creek runs roughly north to south through a steep valley, the morning sun illuminates the west bank first. Because rubyspots cannot fly at low air temperatures unless warmed by the sun directly, roosting on the west bank may enable rubyspots to become 
active and begin hunting earlier in the morning; being active earlier will also reduce their vulnerability to endothermic diurnal predators (especially birds) (Neubauer \& Rehfeldt, 1995). Hunting also occurs primarily along slow sections of the creek, where the largest swarms of prey (e.g. mayflies) occur, during two diurnal periods: just after rubyspots leave the roosts in the morning and just before they enter the roosts in the evening (Grether \& Grey, 1996). Thus the tendency of rubyspots to roost near slowly moving water may simply reflect the value of these areas for hunting; however, because individuals often hunt at locations other than their roosting site (Grether \& Switzer, in press), it is unlikely that hunting site choice is solely responsible for the strong pattern in roost location.

Further observations reveal a seasonal pattern in roosting behavior and a possible adaptive trade-off. In the summers of 1992 and 1993, rubyspots roosted predominantly in the streamside vegetation on the west bank of the creek (unpubl. data), as they did in the summer of 1991 (as presented here), but in the spring and late fall of 1992 and 1993, most roosts were located away from the stream in elevated areas, on large Tamarisk spp. bushes, and occasionally in trees (Pinus sabiniana and Quercus douglasi) (unpubl. data). This seasonal pattern may reflect a trade-off between the benefits of roosting near the stream and the probability of perishing in a flood. Roosting along the stream banks may reduce the cost (energy and/or predation risk) of commuting from roost sites to hunting and mating sites and may also have microclimatic (warmth and humidity) benefits. Floods regularly occur at our study site in the winter and spring (November-May), but during the summer and fall (June-October) floods are exceedingly rare (less than one per decade, according to local ranchers and fire department officials). One of us (GFG) witnessed a rare flash flood on 24 June 1992, which inundated most of the roosts. About $90 \%$ of the marked animals perished; most of the survivors had roosted on high ground several meters from the stream (Grether, unpubl. data). Given that different streams have different cycles and severities of flooding, it follows that the timing of seasonal changes in roosting behavior may vary geographically. It would be interesting to study the roosting behavior of this widespread species in the midwest and eastern United States, where summer thunderstorms are common, or in the tropics where the threat of floods may persist year round.

Although the general roosting areas are predictable, many lines of evidence suggest that within these areas, roosting sites are traditional rather 
than based on habitat characteristics. For example, the roosting sites are not associated with any particular vegetation or habitat characteristic within the suitable roosting areas, with most of the available locations being used at some point during the study. In addition, specific roost sites moved slightly from night to night and larger roosts were more likely to be occupied on subsequent nights, both of which are characteristics consistent with the idea that these sites are traditional. Also, in an experimental study on roost formation and maintenance, we were able to establish roosts in previously unoccupied location s using rubyspot models; some of these roosts continued to be used even after the models were removed (Grether \& Switzer, in press). Population translocation experiments, analogous to those of Warner (1988), could clarify further the relative importance of habitat characteristics and traditionality.

'Traditional' roosting aggregations have been observed in a wide range of taxa, and in some cases the same roost sites have been used consistently for years (e.g. Gambles, 1971; Møller, 1985; Noske, 1985; CloudsleyThompson, 1986; Harper, 1986; Joseph \& Lahiri, 1989; Prentice \& Walker, 1991). However, these studies may include cases in which suitable roost sites were limited in the environment. For example, day-roosting aggregations of the skipper butterfly Celaenorrhinus fritzgaertneri occupy caves during the dry season in Costa Rica (DeVries et al., 1987); habitats such as caves may be limited in many areas. In other cases, the situation seems to mirror that of rubyspots. For instance, Benson \& Emmel (1973) describe a particular night roost aggregation of the daggerwing butterfly Marpesia berania that they observed for 5 months. Although the aggregation occurred in the same general area the whole time, the height of the aggregation and the tree in which the aggregation was found changed over the course of the study. More studies distinguishing between habitat limitation and true traditionality would further our understanding of this interesting phenomenon.

\section{Functions of clustering}

The evidence presented above suggests that rubyspot roosting aggregation $\mathrm{s}$ are not simply the result of a large number of individuals congregating into a relatively small amount of suitable habitat (e.g. Neubauer \& Rehfeldt, 1995). We can therefore reject the non-adaptive hypothesis of habitat limitation as an explanation for their roosting aggregation s and investigate potential functional hypotheses. A number of evolutionary hypotheses have been proposed 
to explain roosting aggregations for a variety of taxa (reviewed in Eiserer, 1984; Caccamise \& Morrison, 1986; Mallett, 1986; Vulinec, 1990; Danchin \& Richner, in press). Many of these hypotheses could conceivably apply to rubyspot aggregations, but the current study, when combined with other aspects of rubyspot biology, allows us to narrow down the list of possible functions. For example, in contrast to reports for at least two other odonates (Calopteryx splendens, Rüppel \& Hilfert, 1997; Nesciothemis nigeriensis, Parr \& Parr, 1974), we observed no matings at roosts during three years of studying the mating and roosting behavior of this species (Grether, 1996b; pers. obs.); therefore, roosts are unlikely to serve a mating function. Furthermore, rubyspot foraging areas are consistently located in the same areas of the creek within and between years and the roosting sites themselves are often located within the best feeding areas (see above). Thus, the information center hypothesis and recruitment center hypothesis, which may apply when foraging sites are ephemeral and hard to locate (Ward, 1965; Ward \& Zahavi, 1973; Danchin \& Richner, in press), can be rejected. The travelcost based, patch-sitting hypothesis can be rejected on the basis of the relative locations of foraging, hunting, and roosting locations (see Introduction; Grether \& Switzer, in press). In addition, although thermoregulatory benefits may explain the general location of most aggregations (e.g. west bank of stream; see above), these benefits are unlikely to explain the need for the aggregations. Tight aggregations in species such as bees may serve to raise the temperature of the group (Wilson, 1971), but no thermal benefits are expected for small ectothermic animals with relatively loose aggregations. Similarly, benefits related to desiccation avoidance (e.g. Friedlander, 1965) are both improbable and unnecessary for loose aggregations that form near streams. Finally, damselflies are preyed upon by a large variety of vertebrate and invertebrate taxa (pers. obs.), which suggests that they are not distasteful or aposematic (Corbet, 1962; Fincke, 1994). They also spend at least the first year of their life as solitary larvae (Corbet, 1962), making it unlikely that aggregations of damselfly adults are kin groups. Therefore, benefits related to the enhancement of predator learning for distasteful species (Arnold, 1978; Pasteels et al., 1983; Brönmark et al., 1984) also fail to explain the function of rubyspot aggregations.

In contrast to the above possibilities, some aspects of rubyspot biology suggest that non-aposematic, anti-predator related functions may be the function of these aggregations. For instance, rubyspots appear to be quite 
vulnerable when roosting; on warm nights they are reluctant to fly, and on cool nights and mornings they are unable to fly and simply drop off the perch when disturbed. When they do move at night, they frequently get caught in spider webs, and individuals that simply drop from a perch occasionally land in the water. Consequently, predation risk from animals such as spiders at night and birds in the morning (both of which have been observed predating roosting rubyspots) may pose a serious threat to their survival (Brönmark et al., 1984; Calvert, 1994).

Thus, aggregating behavior may be favored if the aggregations either (i) decrease the chance of individuals being detected, (ii) increase the chance of successfully detecting a predator and evading capture and/or (iii) dilute predation risk once an aggregation is discovered (Pulliam, 1973; Treisman, 1975; Kenward, 1978; Treherne \& Foster, 1980; Joseph \& Lahiri, 1989). The potential risks of predation may be greater for the brightly colored males because the males may be more conspicuous and thus more likely than the cryptic females to draw a bird's attention to a solitary roost. Indeed, we found that while both sexes aggregated, males were more likely to aggregate than females; this result suggests that males more actively seek clusters than females. However, the increased conspicuousness of males to other rubyspots could also explain the sex bias at a proximate level. Detailed observations of the settlement process could resolve which proximate mechanism results in the sex bias and provide other clues as to the functional significance of roosting behavior in general and the observed sex bias in particular.

A final functional hypothesis, the safe site hypothesis, also remains a viable hypothesis based on our current information. The safe site hypothesis proposes that individuals roost where others are roosting because popular sites are those with histories of less disturbance (e.g. wind, predators, or grazing herbivores) (Mallet, 1986). In support of this hypothesis, the formation of rubyspot roosts is facilitated by conspecific attraction (Grether \& Switzer, in press); however, conspecific attraction is consistent with the above predation-related hypotheses as well. Experimental manipulations of the aggregations themselves, such as changing the location of roosts or the number of individuals in a roost, would help clarify the function of this interesting behavior. 


\section{References}

Arnold, S.J. (1978). The evolution of a special class of modifiable behaviours in relation to environmental pattern. - Am. Nat. 112, p. 415-427.

Benson, W.W. \& Emmel, T.C. (1973). Demography of gregariously roosting populations of the nymphaline butterfly Marpesia berania in Costa Rica. - Ecology 54, p. 327-335.

Brönmark, C., Malmqvist, B. \& Otto, C. (1984). Antipredator adaptations in a neustonic insect (Velia caprai). — Oecologia 61, p. 189-191.

Caccamise, D.F. \& Morrison, D.W. (1986). Avian communal roosting: implications of diurnal activity centers. - Am. Nat. 128, p. 191-198.

Calvert, W.H. (1994). Behavioral responses of monarch butterflies (Nymphalidae) to disturbances in their habitat - a group startle response? - J. Lepid. Soc. 48, p. 157-165.

Cloudsley-Thompson, J.L. (1986). Aggregation by male Psenulus pallipes (Panzer) (Hym., Sphecidae) at night. — Entomol. Monthly Mag. 122, p. 126.

Copp, N.H. (1983). Temperature-dependent behaviours and cluster formation by aggregating ladybird beetles. - Anim. Behav. 31, p. 424-430.

Corbet, P.S. (1962). A biology of dragonflies. — Quadrangle Books, Chicago.

Danchin, E. \& Richner, H. (in press). Viable and unviable hypotheses for the evolution of raven roosts. - Anim. Behav.

DeVries, P.J., Schull, J. \& Greig, N. (1987). Synchronou s nocturnal activity and gregarious roosting in the neotropical skipper butterfly Celaenorrhinus fritzgaertneri (Lepidoptera: Hesperiidae). — Zool. J. Linn. Soc. 89, p. 89-103.

Eiserer, L. (1984). Communal roosting in birds. - Bird Behav. 5, p. 61-80.

Fincke, O.M. (1994). Female colour polymorphism in damselflies: failure to reject the null hypothesis. - Anim. Behav. 47, p. 1249-1266.

Friedlander, C.P. (1965). Aggregation in Oniscus asellus. - Anim. Behav. 13, p. 342-346.

Gambles, R.M. (1971). Dragonfly dormitories. — Niger. Fld. 36, p. 166-170.

Greig, N. \& DeVries, P.J. (1986). Observations on the diurnal gregarious roosting of Ocalaria sp. (Noctuidae) in Costa Rica. - J. Lepid. Soc. 40, p. 124-126.

Grether, G.F. (1996a). Intrasexual competition alone favors a sexually dimorphic ornament in the rubyspot damselfly Hetaerina americana. — Evolution 50, p. 1949-1957.

— — (1996b). Sexual selection and survival selection on wing coloration and body size in the rubyspot damselfly Hetaerina americana. — Evolution 50, p. 1939-1948.

— — \& Grey, R.M. (1996). Novel cost of a sexually-selected trait in the rubyspot damselfly Hetaerina americana: conspicuousness to prey. — Behav. Ecol. 7, p. 465-473.

- — \& Switzer, P.V. (in press). Mechanisms for the formation and maintenance of traditional night roost aggregations in a territorial damselfly. - Anim. Behav.

Harper, D. (1986). Communal roosting by robins Erithacus rubecula. - Bird Study 33, p. 223-226.

Joseph, K.J. \& Lahiri, A.R. (1989). The diel patterns of communal roosting behaviour in the dragonfly Potamarcha congener (Rambur) (Anisoptera: Libellulidae). - Adv. Odonatol. 4, p. 45-52.

Kenward, R.E. (1978). Hawks and doves: factors affecting success and selection in goshawk attacks on wood-pigeons. - J. Anim. Ecol. 47, p. 449-460.

Mallet, J. (1986). Gregarious roosting and home range in Heliconius butterflies. - Nat. Geogr. Res. 2, p. 198-215. 
Miller, P.L. (1989). Communal roosting in Potamarcha congener (Rambur) and its possible functions (Anisoptera: Libellulidae). — Odonatologica 18, p. 179-194.

Møller, A.P. (1985). Communal roosting in the magpie (Pica pica). - J. Ornithol. 126, p. $405-419$.

Neubauer, K. \& Rehfeldt, G. (1995). Roosting site selection in the damselfly species Calopteryx haemorrhoidalis (Odonata: Calopterygidae). — Entomol. Gener. 19, p. 291302.

Noske, R.A. (1985). Huddle-roosting behaviour of the varied sittella Daphoenositta chrysoptera in relation to social status. - Emu 85, p. 188-194.

Parr, M.J. \& Parr, M. (1974). Studies on the behaviour and ecology of Nesciothemis nigeriensis Gambles (Anisoptera: Libellulidae). — Odonatologica 3, p. 21-47.

Pasteels, J.M., Gregoire, J.C. \& Rowell-Rahier, M. (1983). The chemical ecology of defense in arthropods. - Ann. Rev. Entomol. 28, p. 263-289.

Prentice, T.R. \& Walker, G.P. (1991). Nocturnal clustering of the solitary wasp, Chalybion californicum (Saussure) (Hymenoptera: Sphecidae). — Pan-Pacif. Entomol. 67, p. 222224.

Pulliam, H.R. (1973). On the advantages of flocking. - J. theor. Biol. 38, p. 419-422.

Rau, P. \& Rau, N. (1916). The sleep of insects: an ecological study. — Ann. Ent. Soc. Am. 9, p. 227-274.

Rüppel, G. \& Hilfert, D. (1997). Alternative mating tactics in Calopteryx splendens (Odonata: Calopterygidae). - In: Advances in Ethology, 32. Contributions to the XXV International Ethological Conference, Vienna, Austria. (M. Taborsky \& B. Taborsky, eds). Blackwell Wissenschafts-Verlag GmbH, Berlin, Germany, p. 47.

Treherne, J.E. \& Foster, W.A. (1980). The effects of group size on predator avoidance in a marine insect. - Anim. Behav. 28, p. 1119-1122.

Treisman, M. (1975). Predation and the evolution of gregariousness: I. Models for concealment and evasion. - Anim. Behav. 23, p. 779-800.

Vulinec, K. (1990). Collective security: aggregation by insects as a defense. - In: Insect defenses (D.L. Evans \& J.O. Schmidt, eds). State University of New York Press, Albany. p. 251-288.

Ward, P. (1965). Feeding ecology of the black-faced dioch, Quelea quelea, in Nigeria. — Ibis 107, p. 173-214.

— — \& Zahavi, A. (1973). The importance of certain assemblages of birds as information centres' for food finding. - Ibis 115 , p. 517-534.

Warner, R.R. (1988). Traditionality of mating-site preferences in a coral reef fish. - Nature 335, p. $719-721$.

Wilson, E.O. (1971). The insect societies. - Harvard University Press, Cambridge.

Wynne-Edwards, V.C. (1962). Animal dispersion. - Oliver and Boyd, Edinburgh. 